\title{
MODEL PEMBELAJARAN BERBASIS PROYEK (PROJECT BASED LEARNING) UNTUK MENINGKATKAN HASIL BELAJAR
}

\author{
Ramadhan Indra Setyawan $^{1)}$, Drs. Agus Purwanto ${ }^{2)}$, Nurratri Kurnia Sari ${ }^{3)}$ \\ ${ }^{1}$ PGSD, Universitas Veteran Bangun Nusantara Sukoharjo \\ Email: ramadhanindra505@gmail.com \\ ${ }^{2}$ PGSD, Universitas Veteran Bangun Nusantara Sukoharjo \\ Email: aguspuerwanto@univetbantara.ac.id \\ ${ }^{3}$ PGSD, Universitas Veteran Bangun Nusantara Sukoharjo \\ Email: nurratrikurniasari@ univetbantara.ac.id
}

\begin{abstract}
Abstrak
Penelitian ini bertujuan Untuk meningkatkan hasil belajar tematik melalui penerapan model pembelajaran berbasis proyek (Project Based Learning) pada siswa kelas IV SD Negeri Sugihan 03 Sukoharjo tahun pelajaran 2018/2019.Penelitian ini merupakan penelitian tindakan kelas (PTK). Penelitian ini menerapkan model pembelajaran berbasis proyek (Project Based Learning). Penelitian ini dilaksanakan dalam 3 siklus terdiri dari perencanaan, pelaksanaan tindakan, observasi, dan refleksi. Subyek penelitian adalah guru dan siswa kelas IV semester II SD Negeri Sugihan 03 Sukoharjo tahun ajaran 2018/2019 yang berjumlah 20 siswa, terdiri dari 11 siswa laki-laki dan 9 siswa perempuan. Teknik pengumpulan data melalui wawancara, observasi, tes, dan dokumentasi. Setiap siswa dikatakan tuntas belajarnya (ketuntasan individu) jika proporsi jawaban benar siswa $\geq 65 \%$, dan suatu kelas dikatakan tuntas belajarnya (ketuntasan klasikal) jika dalam kelas tersebut terdapat $\geq 85 \%$ siswa yang telah tuntas belajarnya. Hasil penelitian menunjukkan (1) persentase ketuntasan hasil belajar tematik siswa kelas IV yang semula pada prasiklus adalah 25\% yang mencapai KKM kemudian pada siklus I meningkat menjadi $60 \%$, kemudian pada siklus II meningkat menjadi $75 \%$ dan pada siklus III mencapai 95\% sehingga penelitian tindakan kelas dengan menggunakan model pembelajaran berbasis proyek dinyatakan berhasil dan sudah teruji.
\end{abstract}

Kata Kunci : Hasil belajar tematik, model pembelajaran berbasis proyek (Project Based Learning).

\begin{abstract}
This study aims to improve the results of thematic learning through the application of project-based learning models (Project Based Learning) in fourth grade students of SD Negeri Sugihan 03 Sukoharjo in the 2018/2019 academic year. This research is a classroom action research (CAR). This study applies a project-based learning model (Project Based Learning). This research was conducted in 3 cycles consisting of planning, implementing actions, observing, and reflecting. The research subjects were teachers and fourth grade students of the second semester of SD Negeri Sugihan 03 Sukoharjo in the 2018/2019 school year, totaling 20 students, consisting of 11 male students and 9 female students. Data collection techniques through interviews, observation, tests, and
\end{abstract}


documentation. Each student is said to have completed learning (individual completeness) if the proportion of correct answers of students $\geq 65 \%$, and a class is said to have completed learning (classical completeness) if in the class there are $\geq 85 \%$ of students who have finished learning. The results showed (1) the percentage of completeness of the thematic learning outcomes of Grade IV students, which in the prasiklus was $25 \%$ which reached KKM then in cycle I increased to $60 \%$, then in cycle II it increased to $75 \%$ and in cycle III it reached $95 \%$ so that research classroom action using the project-based learning model is declared successful and has been tested.

Keywords: Thematic learning outcomes, project-based learning models (ProjectBased Learning).

\section{PENDAHULUAN}

Pendidikan memiliki peranan yang sangat penting dalam kehidupan manusia, karena dengan pendidikan kemampuan dan kepribadian manusia dapat berkembang. Pendidikan menyangkut hati nurani, nilai-nilai, perasaan, pengetahuan, dan keterampilan. Melalui pendidkan manusia berusaha meningkatkan dan mengembangkan serta memperbaiki nilai-nilai, hati nuraninya, perasaannya, pengetahuannya dan keterampilannya.

Nana Sudjana (2004) menyatakan Perilaku pasif adalah perilaku yang tidak menyatakan perasaan, gagasan dan kebutuhannya dengan tepat serta mengabaikan hak-haknya sendiri. Perilaku pasif ini biasanya bersifat emosional, tidak jujur dan tidak langsung, terhambat dan menolak diri sendiri. Sehingga siswa kemudian cenderung tidak tertarik dengan pembelajaran yang diberikan oleh guru. Hal itu yang menyebabkan hasil belajar yang kurang optimal.

Salah satu indikator kesuksesan pelaksanaan pendidikan ialah tingginya mutu sumber daya manusia yang dihasilkan. Sedangkan salah satu bentuk keberhasilan pendidikan dapat terlihat dari keberhasilan pembelajaran. Apabila pembelajaran berjalan dengan baik maka diharapkan hasil belajar yang diraih siswa juga baik.

Jihad dan Haris (2012) mengungkapkan bahwa hasil belajar merupakan pencapaian dalam bentuk perubahan perilaku yang cenderung menetap dari ranah kognitif, afektif, dan psikomotoris dari proses belajar yang dilakukan dalam waktu tertentu. Oleh karena itu dapat dikatakan bahwa hasil belajar merupakan perolehan dari proses belajar siswa sesuai dengan tujuan pengajaran. 
Menurut Undang-Undang Nomor 20 Tahun 2003 tentang Sistem Pendidikan Nasional Bab I Pasal I Ayat I menjelaskan bahwa pendidikan adalah usaha sadar dan terencana untuk mewujudkan suasana belajar dan proses pembelajaran agar peserta didik secara aktif mengembangkan potensi dirinya untuk memiliki kekuatan spiritual keagamaan, pengendalian diri, kepribadian, kecerdasan, akhlak mulia, serta keterampilan yang diperlukan dirinya, masyarakat, bangsa dan negara.

Ayat dari Undang-Undang tersebut menerangkan bahwa pendidikan merupakan usaha yang dirancang secara sengaja untuk menjadikan manusia dalam hal ini adalah siswa berhasil dalam kehidupannya. Untuk mencapai tujuan pendidikan seutuhnya, maka sekolah merupakan salah satu tempat yang tepat bagi siswa dalam mengembangkan potensi diri sesuai dengan tujuan yang diharapkan (Susanto, 2013).

Hal tersebut mendasari terbentuknya Permendiknas nomor 22 tahun 2006 yang mengatur tentang standar isi untuk satuan pendidikan dasar dan menengah. Di dalamnya telah diatur materi minimal dan tingkat kompetensi minimal untuk mencapai kompetensi lulusan minimal pada jenjang dan jenis pendidikan tertentu, termasuk di dalamnya adalah sekolah dasar.

Dalam Susanto (2013) Standar Kompetensi Lulusan Satuan Pendidikan pada SD/MI diantarannya yaitu menjalankan ajaran agama yang dianut sesuai dengan tahap perkembangan anak, mengenal kekurangan dan kelebihan diri sendiri, mematuhi aturan-aturan sosial yang berlaku dalam lingkungannya, menghargai keberagaman, menggunakan informasi tentang lingkungan, menunjukan kemampuan berpikir dengan bimbingan guru, menunjukan rasa keingintahuan yang tinggi dan kemampuan memecahkan masalah, menunjukan kecintaan dan kepedulian terhadap lingkungan, kecintaan dan kebanggaaan terhadap bangsa, kemampuan untuk melakukan kegiatan seni dan budaya lokal, menunjukan kebiasaan hidup sehat dan memanfaatkan waktu luang, berkomunikasi secara jelas dan santun, bekerja sama dan tolong menolong serta menjaga diri sendiri dalam lingkungan keluarga dan teman sebaya, menunjukan kegemaran membaca dan menulis, serta menunjukan keterampilan menyimak, 
berbicara, membaca, menulis dan berhitung. Dari uraian tersebut, dapat dipahami bahwa tujuan pendidikan di sekolah dasar dimaksudkan untuk membentuk manusia yang memiliki karakter serta kepribadian yang mulia, kreatif, kritis, santun, taat beragama, peduli terhadap sesama manusia dan lingkungan alam sekitar, bekerja sama, dan saling menolong. Sedangkan tujuan akhir dari pendidikan dasar ialah diperolehnya pengembangan pribadi siswa yang membangun dirinya dan ikut serta bertanggung jawab terhadap pengembangan bangsa, mampu melanjutkan ke tingkat pendidikan yang lebih tinggi dan mampu mengembangkan diri sesuai dengan bakat, minat, kemampuan, dan lingkungannya. Apabila siswa mampu memenuhi standar tersebut, maka dikatakan berhasil dan dapat melanjutkan ke tahap berikutnya.

Untuk mencapai tujuan akhir pendidikan perlu kerja sama yang baik antar semua pihak yang terkait. Tanggung jawab pendidikan merupakan tanggung jawab bersama antara keluarga, masyarakat, dan pemerintah. Pemerintah tidak boleh memonopoli semuanya, melainkan bersama dengan keluarga dan masyarakat berusaha agar pendidikan mencapai tujuan yang telah ditentukan (Munib, 2012).

Dimyati dan Mudjiono (2013) mengungkapkan bahwa hasil belajar berupa kapabilitas yang timbul dari rangsangan yang berasal dari lingkungan dan proses kognitif yang dilakukan oleh pelajar. Dengan demikian dapat dikatakan bahwa hasil belajar tidak hanya dipengembangani oleh kegiatan pembelajaran di sekolah namun, juga karena rangsangan dari lingkungan sekitar.

Menurut Mulyono (2001) Guru memiliki peran dan tanggung jawab yang besar dalam proses pembelajaran. Seorang guru harus mampu menerapkan pembelajaran yang aktif, inovatif, kreatif, dan menyenangkan, sehingga menimbulkan ketertarikan siswa untuk belajar. Penerapan model project based learning diharapkan dapat memberikan semangat kepada siswa dalam pembelajaran Tematik, dapat mengarahkan kepada pembelajaran yang aktif, kreatif, inovatif, dan menyenangkan. Siswa menjadi lebih memahami materimateri pembelajaran yang disampaikan. Sehingga diharapkan dapat meningkatkan hasil belajar siswa. 
Trianto Ibnu Badar Al-Tabany (2014) berpendapat, "Project based learning merupakan pembelajaran inovatif yang berpusat pada siswa (student centered) dan menempatkan guru sebagai motivator dan fasilitator, di mana siswa diberi peluang bekerja secara otonom mengkonstruksi belajarnya".

Dari beberapa pendapat tersebut, dapat disimpulkan bahwa project based learning merupakan pembelajaran aktif, inovatif dan menyenangkan yang menggunakan proyek/kegiatan sebagai tujuannya dan pada akhirnya menghasilkan karya nyata yang dapat diperlihatkan seperti laporan, karangan, dan penyelesaian tugas tertulis. Dalam pembelajaran Tematik proyek yang dikerjakan siswa dapat berupa proyek perkelompok berbentuk laporan yang dilaksanakan dalam jangka waktu tertentu, kemudian ditampilkan atau dipresentasikan. Kegiatan pembelajaran ini memberi kesempatan kepada siswa untuk merangkum pengetahuan dari berbagai sumber dan mengaplikasikannya dalam sebuah hasil karya berupa produk.

\section{METODE PENELITIAN}

Jenis penelitian yang dilaksanakan oleh peneliti adalah Penelitian Tindakan Kelas (Classroom Action Research). Penelitian ini lebih bersifat mendeskripsikan data, fakta dan keadaan yang ada di lapangan dengan menggunakan model siklus yang dilaksanakan sebanyak tiga tahap pada satu sekolah dengan siswa kelas IV. Penelitian dilaksanakan di SD Negeri Sugihan 03 Sukoharjo bertindak sebagai subjek yang melakukan tindakan kelas. Teman sejawat dan guru kelas bertindak sebagai observer. Kepala Sekolah bertindak sebagai subjek yang membantu dalam perencanaan dan pengumpulan data. Subjek yang menerima tindakan kelas adalah siswa kelas IV SD Negeri Sugihan 03 Sukoharjo semester II tahun ajaran 2018/2019 sebanyak 20 siswa.

Teknik pengumpulan data yang digunakan adalah : tes, observasi, wawancara dan dokumentasi. Tes adalah serentetan pertanyaan atau latihan serta alat lainyang digunakan untuk mengukur keterampulan, pengetahuan intelegensi, kemapuan atau bakat yang dimiliki oleh individu dan kelompok (Arikunto, 2010). 
Tes merupakan serentetan pertanyaan atau latihan serta alat lain yang digunakan untuk mengukur keterampilan, pengetahuan intelegensi kemampuan atau bakat yang dimiliki oleh individu atau kelompok (Arikunto, 2013). Tes berupa soal pilihan ganda. Tes dilakukan pada siswa kelas IV Sekolah Dasar Negeri Sugihan 03 dan Sekolah Dasar Negeri Jetis 03 tahun ajaran 2019/2020 yang bertujuan untuk mengetahui pemanfaatan model pembelajaran berbasis proyek (Based Learning Project) terhadap hasil belajar siswa kelas IV setelah adanya perlakuan pada kelas eksperimen.

Observasi adalah pengamatan secara langsung terhadap suatu objek penelitian yang terdapat di lingkungan, baik yang sedang berlangsung saat itu atau masih berjalan yang meliputi berbagai aktifitas perhatian terhadap suatu kajian objek dengan menggunakan penginderaan. Pada penelitian ini, peneliti menggunakan observasi non partisipatif karena peneliti tidak terlibat dan hanya mengamati, mencatat, menganalisis serta menyimpulkan peranan guru kelas IV SD Negeri Sugihan 03. Bertujuan menggambarkan segala sesuatu yang berhubungan dengan objek penelitian, mengambil kesimpulan yang disusun menjadi sebuah laporan yang relevan dan dapat bermanfaat sebagai sebuah bahan pembelajaran atau studi.

Instrumen penelitian adalah suatu alat digunakan untuk mengukur variabel penelitian (Sugiyono, 2013).

a. Lembar wawancara dalam bentuk tersruktur jadi untuk pertanyaan sudsh dibuat oleh peneliti sebelum dilaksanakan wawancara bersama guru kelas.

b. Tes yang digunakan dalam bentuk soal pilihan ganda 15 dan essay 5 .

c. Lembar observasi dalam bentuk terbuka sehingga bisa mengamati objek penelitian.

d. Kisi-kisi yang digunakan sesuai dengan Standart Kompetensi.

Indikator kinerja merupakan rumusan kinerja yang akan dijadikan acuan atau tolak ukur dalam menentukan keberhasilan atau keefektifan penelitian. Indikator kinerja yang ingin dicapai dalam penelitian tindakan kelas ini adalah meningkatkan hasil belajar siswa SD Negeri Sugihan 03 Sukoharjo tahun 
pelajaran 2018/2019 dengan menggunakan model pembelajaran berbasis proyek (Project Based Learning).

Setiap siswa dikatakan tuntas belajarnya (ketuntasan individu) jika proporsi jawaban benar siswa $\geq 65 \%$, dan suatu kelas dikatakan tuntas belajarnya (ketuntasan klasikal) jika dalam kelas tersebut terdapat $\geq 85 \%$ siswa yang telah tuntas belajarnya (Depdikbud dalam Trianto, 2010). Target ketuntasan secara nasional diharapkan mencapai minimal 75. Satuan pendidikan dapat memulai dari kriteria ketuntasan minimal di bawah target nasional kemudian ditingkatkan secara bertahap. (Winkel 1996).

\section{HASIL PENELITIAN DAN PEMBAHASAN}

\section{a. Hasil Penelitian}

Pada awal pembelajaran siswa kurang antusias mengikuti pembelajaran masih belum maksimal, belum mencapai kriteria ketuntasan minimal (KKM) yaitu ditetapkan 75. Model yang digunakan masih dominan ceramah belum menggunakan model yang dapat mengaktifkan siswa dan dapat bekerjasama dengan teman serta model pembelajaran juga masihh sangat kurat efektif. Pembelajaran masih berpusat pada guru (Teacher Centered) pola interaksi searah dari guru kepada siswa, siswa cenderung pasif, hanya duduk, mendengarkan dan mencatat. Nilai rata-rata yang dicapai dari 20 siswa adalah 61,8 serta ada 2 siswa yang mendapatkan nilai 30, ada 2 siswa yang mendapatkan 40, ada 6 siswa mendapakan 50, ada 5 siswa yang mendapatkan 60, ada 3 siswa yang mendapatkan 70 dan ada 2 siswa yang mendapatkan nilai 80. Berikut ini tabel perolehan ketuntasan hasil belajar tematik pada kondisi awal prasiklus :

Tabel 1. Perolehan Ketuntasan hasil belajar Tematik pada kondisi awal

\begin{tabular}{cc}
\hline Siswa yang tuntas & Siswa yang tidak tuntas \\
\hline $5(25 \%)$ & $25(75 \%)$ \\
\hline
\end{tabular}

Kegiatan penelitian dilakukan sebanyak tiga kali pertemuan dengan menerapkan model pembelajaran project based learning yang bertujuan agar 
siswa mengembangkan ide kreatif, aktif dan kritis dalam pembelajaran sehingga siswa dapat menciptakan suasana belajar, produk kreatifitasnya dan hasil belajar memuaskan. Perangkat pembelajaran yang digunakan yaitu Silabus, RPP, dan soal.

Tabel 2 Perolehan Ketuntasan Hasil Belajar Tematik Siklus I

\begin{tabular}{cc}
\hline Siswa yang tuntas & Siswa yang tidak tuntas \\
\hline $12(60 \%)$ & $8(40 \%)$ \\
\hline
\end{tabular}

Berdasarkan tabel tersebut dapat diketahui bahwa pembeajaran tematik pada pertemuan kedua ada peningkatan terdapat hasil belajar menajdi 12 siswa (60\% dari jumlah siswa dikelas) yang mencapai KKM kemudian pada siklus II mengalami penurunan menjadi 8 siswa (40\% dari jumlah siswa dikelas).

Tabel 3 Perolehan Ketuntasan Hasil Belajar Tematik Siklus II

\begin{tabular}{cc}
\hline Siswa yang tuntas & Siswa yang tidak tuntas \\
\hline $15(75 \%)$ & $5(25 \%)$ \\
\hline
\end{tabular}

Berdasarkan tabel tersebut dapat diketahui bahwa pembeajaran tematik pada pertemuan kedua ada peningkatan terdapat hasil belajar menajdi 15 siswa (75\% dari jumlah siswa dikelas) yang mencapai KKM kemudian pada siklus II mengalami penurunan menjadi 5 siswa (25\% dari jumlah siswa dikelas).

Tabel 4. Perolehan Ketuntasan Hasil Belajar Tematik Siklus III

\begin{tabular}{cc}
\hline Siswa yang tuntas & Siswa yang tidak tuntas \\
\hline $19(95 \%)$ & $1(5 \%)$ \\
\hline
\end{tabular}

Berdasarkan tabel tersebut dapat diketahui bahwa pembeajaran tematik pada pertemuan kedua ada peningkatan secara signifikan yang ditunjukan pada hasil belajar menjadi 19 siswa (95\% dari jumlah siswa dikelas) yang mencapai KKM kemudian pada siklus III mengalami penurunan menjadi 1 siswa (5\% dari jumlah siswa dikelas) sehingga pada penelitian ini dirasa berhasil dengan menerapkan model pemeblajaran berbasis proyek.

\section{b. Pembahasan}


Hasil penelitian pada kondisi awal pelaksanaan siklus I, siklus II dan siklus III diperoleh data yang ditabulasikan sebagai berikut :

Tabel 5. Perbandingan Hasil ketuntasan

\begin{tabular}{lccccc}
\hline No & Hasil Siswa & Kondisi Awal & Siklus I & Siklus II & Siklus III \\
\hline 1 & Siswa yang tuntas & $\mathbf{2 5 \%}$ & $\mathbf{6 0 \%}$ & $\mathbf{7 5 \%}$ & $\mathbf{9 5 \%}$ \\
2 & Siswa yang tidak tuntas & $\mathbf{7 5 \%}$ & $\mathbf{4 0 \%}$ & $\mathbf{2 5 \%}$ & $\mathbf{5 \%}$ \\
\hline
\end{tabular}

Hasil belajar tematik siswa kelas IV SD Negeri Sugihan 03 tahun ajaran 2018/2019 dapat dikatakan masih rendah, hal ini dapat dilihat dari persentase ketuntasan belajar siswa yang hanya mencapai $25 \%$. Hal ini dikarenakan penyampaian materi yang dilakukan guru kurang melibatkan siswa secara aktif untuk menysuusn dan menemukan sendiri konsep materi ajar, keadaan siswa yang bosan dalam proses pembelajaran dan kurang memiliki rasa ingin tahu terhadap materi ajar, pengemasan kegiatan belajar mengajar (KBM) yang kurang menarik karena tidak adanya pengadaan media pembelajaran dan interaksi kegiatan belajar mengajar yang hanya berlangsung 1 arah aitu dari guru ke siswa. Hal ini menjadikan motivasi belajar siswa rendah dan berimbas pada hasil belajar siswa.

Untuk mengatasi masalah rendahnya hasi belajar siswa ini maka peneliti melakukan Penelitian Tindakan Kelas (PTK) pada mata pelajaran tematik dengan menerapkan model pembelajaran berbasis proyek (Project Based Learning). Pada pelaksanaan pembelajaran Tematik pra siklus yang dilaksanakan sebelum tindakan siswa kelas IV SD Negeri Sugihan 03 Sukoharjo tahun pelajaran 2018/2019 menunjukan hasil belajar siswa masih rendah yaitu rata-rata nilai 61,8; nilai terendah 30 , nilai tertinggi 84 , dan hanya ada 5 siswa atau $25 \%$ yang mampu mencapai nilai KKM, sedangkan 15 siswa atau $75 \%$ belum mampu mencapai nilai KKM. Kemudian peneliti mengadakan penelitian untuk meningkatkan hasil belajar siswa pada mata pelajaran Tematik dengan menerapkan model pemebelajaran berbasis proyek.

Setelah pelaksanaan tindakan penelitian siklus I, hasil belajar siswa kelas IV SD Negeri Sugihan 03 Sukoharjo tahun ajaran 2018/2019 telah mengalami 
peningkatan walapun belum signifikan yaitu rata-rata nilai 69,6; dengan nilai terendah 40, nilai tertinggi 75, dari jumlah keseluruhan siswa yaitu sebanyak 20 siswa terdapat 12 siswa 60\% kategori sudah cukup mencapai KKM pada siklus I, sedangkan 8 siswa 40\% kategori belum mencapai KKM. Hasil belajar siswa pada siklus I ini telah mengalami peningkatan cukup baik, tetapi belum mencapai indikator kinerja $85 \%$ sehingga penelitian harus dilanjutkan ke siklus selanjutnya yaitu siklus II.

Peneliti dan guru kelas IV berdiskusi untuk mencari kekurangan pada siklus I dari berbagai faktor seperti : Guru kurang menguasai kelas, siswa cenderung bosan, kurang menyenangkan, siswa masih asyik berbicara dengan temannya, pengemasan Kegiatan Belajar Mengajar (KBM). Untuk mengatasi kekurangan yang terjadi pada siklus I, maka dilaksanakan siklus II. Hasil belajar siswa telah mengalami peningkatan signifikan yaitu rata-rata nilai 79,4; dengan nilai terendah 65, nilai tertinggi 93, dari jumlah keseluruhan siswa yaitu sebanyak 20 siswa terdapat 15 siswa 75\% kategori sudah mencapai KKM pada siklus II, sedangkan 5 siswa 25\% kategori belum mencapai KKM. Hasil belajar siswa pada siklus II ini telah mengalami peningkatan cukup baik, tetapi belum mencapai indikator kinerja $85 \%$ sehingga penelitian harus dilanjutkan ke siklus selanjutnya yaitu siklus III. Setelah melaksanakan siklus I dan siklus II hasil belajar sudah mengalami grafik peningkatan secara signifikan walapun masih belum mampu menembus atau mencapai terget indikator kinerja. Pada siklus III peneliti dan guru berusaha memaksimalkan perangkat pembelajaran berupa : Buku, LKS, Media dan Model pembelajaran untuk dikemas semenarik mungkin agar peneran sistem Student Center lebih efektif dan efisien untuk kegiatan belajar mengajar siswa agar dalam suasana KBM lebih menyenangkan, memunculkan ide-ide kreatif dan inovatif dalam hasil sebuah produk karya siswa kelas IV SD Negeri Sugihan 3.

Setelah pelaksanaan siklus III ternyata siswa sudah memahami kegiatan elajar mengajar dengan Student Center dan peran guru disini hanya sebagai Fasilitator, Pengawas, Controling, Evaluasi dan Refleksi sudah berjalan sebagai 
mestinya. Hasil belajar siswa kelas IV pada siklus III mengalami peningkatan secara signifikan yaitu rata-rata nilai 82,2 ; dengan nilai terendah 74 , nilai tertinggi 95, dari jumlah keseluruhan siswa yaitu sebanyak 20 siswa terdapat 19 siswa 95\% kategori sudah mencapai KKM pada siklus III, sedangkan 1 siswa 5\% kategori belum mencapai KKM. Pada siklus III persentase ketuntasan siswa telah mencapai target indikator kinerja bahkan melebihi indikator yang ditentukan yyaitu 95\%, sehingga penelitian berhasil dan dinyatakan selesai sampai pada siklus III.

Berdasarkan data penelitian tersebut, kegiatan belajar mengajar yang dilaksanakan dengan menerapkan model pembelajaran berbasis proyek (Project Based Learning) dapat meningkatkan hasil belajar siswa dan membuat kegiatan belajar mengajar menjadi Student Center atau pembelajaran terpusat pada siswa, siswa menjadi lebih berkembang serta mengembangkan pembelajarannya sendiri dengan ide-ide yang mereka gali, munculnya kreatifitas, inovasi dalam impelementasi untuk menjadi sebuah media atau produk karya siswa tersebut. Hal ini bisa dilihat dari ketertarikan siswa dalam kegiatan belajar, tertantang untuk mengembangkan ide-ide kreatif, inovatif, daya jelajah dan rasa ingin tahu terhadap materi yang diberikan oleh guru.

Dengan demikian hipotesis yang berbunyi "Penerapan model pembelajaran berbasis proyek (Project Based Learning) dapat meningkatkan hasil belajar siswa pada materi tematik kelas IV SD Negeri Sugihan 03 Sukoharjo tahun pelajaran 2018/2019." telah teruji kebenarannya. Untuk memperjelas, berikut ini disajikan diagram batang persentase perbandingan hasil belajar tematik siswa prasiklus, siklus II dan siklus III: 


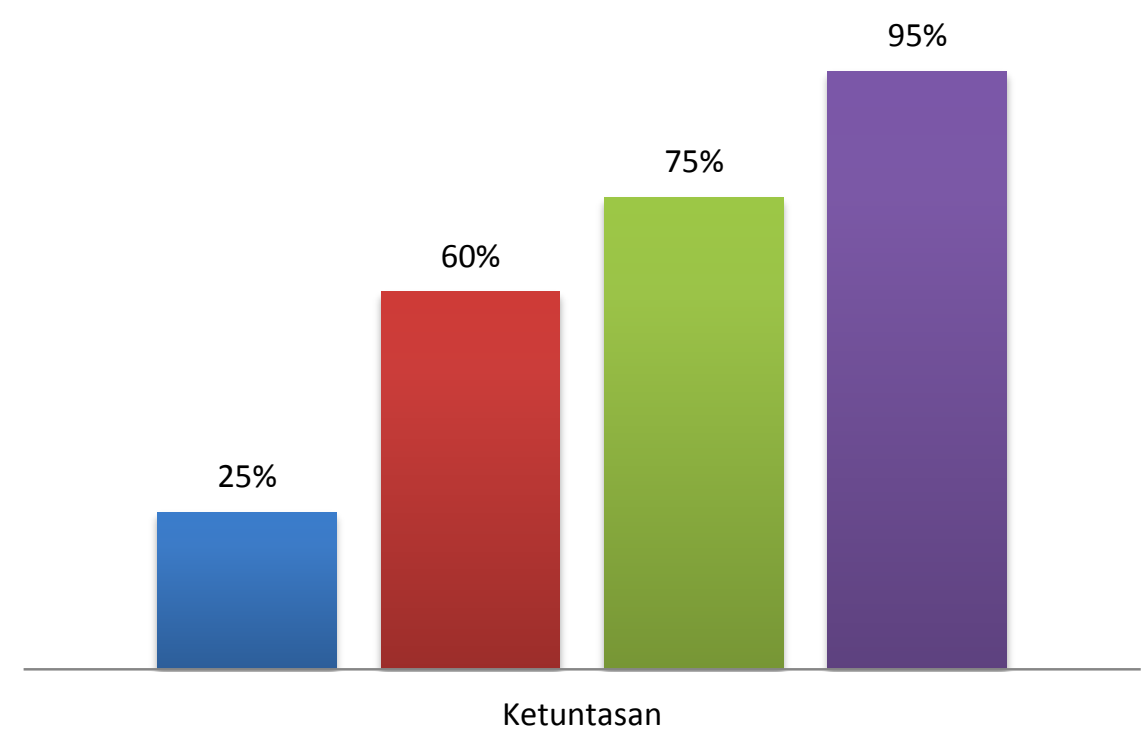

Gambar 1. Peningkatan hasil belajar siswa dalam pembelajaran tematik
Keterangan : a. Prasiklus (25\%)
b. Siklus I (60\%)
c. Siklus II $(75 \%)$
d. Siklus III (95\%)

\section{SIMPULAN}

Berdasarkan hasil pembahasan, dapat disimpulkan bahwa penelitian tindakan kelas melalui penerapan model pembelajaran berbasis proyek (Project Based Learning) dapat meningkatkan hasil belajar pada siswa kelas IV SD Negeri Sugihan 03.

Berdasarkan kesimpulan diatas, dapat memberikan implikasi bahwa menerapkan model pembelajaran berbasis proyek (Project Based Learning) dapat meningkatkan hasil belajar siswa dalam pembelajaran Tematik. Maka hal ini menunjukan bahwa menerapkan model pembelajaran berbasis proyek (Project Based Learning) sangat membantu dalam usaha peningkatan hasil, pembelajaran menarik, menantang, kreatif, inovatif dan menyenangkan. Ketercapaian mampu membuat pembelajaran menjadi terpusat ke siswa sehingga siswa memahami dan mengerti belajar dengan mengembangkan ide kreatif dalam membuat media belajarnya sendiri. Hal ini berujung dalam meningkatkan kualitas pendidikan mulai dari Sumber Daya Manusia dan Sarana Prasana pendukung sebagai upaya ketercapian keberhasilan pendidikan. 


\section{REFERENSI}

Abdul Munib, dkk. 2012. Pengantar Ilmu Pendidikan. Semarang :UNNES Pres Sudjana, Nana. 2004. Dasar-dasar Proses BelajarMengajar. Bandung:SinarBaruAlgensido Offset

Al-Tabany, Trianto Ibnu Badar. 2014. Mendesain Model Pembelajaran Inovatif, Progresif, dan Kontekstual. Jakarta: Prenadamedia Group.

Anton, M, Mulyono. 2001. Aktivitas Belajar. Bandung. Yrama

Dimyati dan Mudjiono. 2002. Belajar dan Pembelajaran. Jakarta: Rineka Cipta

Jihad Asep \& Abdul haris.2012.Evaluasi Pembelajaran. Yogyakarta:Multi Presindo

Sugiyono. 2013. Metode Penelitian Pendidikan Pendidikan Kuantitatif. Bandung: Alfabeta.

Susanto, Ahmad. 2013. Teori Belajar dan Pembelajaran di Sekolah Dasar. Jakarta: Prenadamedia Group.

Trianto. 2010. Mendesain Model Pembelajaran Inovatif-Progresif, Surabaya

W.S. Winkel. 1996. Psikologi Pengajaran. Jakarta: Gramedia 